\title{
Elaiophores in three Neotropical Malpighiaceae species: a comparative study
}

\author{
Clivia C. F. Possobom ${ }^{1}$ Silvia R. Machado ${ }^{2}$
}

Received: 21 November 2016 / Accepted: 28 June 2017 / Published online: 25 July 2017

(c) Springer-Verlag GmbH Austria 2017

\begin{abstract}
Malpighiaceae species are recognized for their sepal elaiophores of which secretions reward oil-collecting bees. Information on elaiophore location, structure and functioning is likely to provide valuable insights into pollination ecology and evolution of the family. We characterized the elaiophores in three Malpighiaceae species and compared the patterns of distribution and dimensions of these glands, their structural organization, their histochemistry and their life spans. Intact elaiophores from buds and 1-day flowers (bagged and un-bagged) of Banisteriopsis variabilis, Byrsonima coccolobifolia and Peixotoa reticulata were collected for structural, histochemical and ultrastructural studies. We also reported the behavior of elaiophore-visiting insects. Elaiophores exhibit uniseriate secretory epithelium covered by a thick cuticle and vascularized parenchyma. The secretory surfaces can be flat (B. coccolobifolia and P. reticulata) or convoluted ( $B$. variabilis). In $B$. variabilis and $P$. reticulata the epithelium has longer cells than in B. coccolobifolia and these become papillose, taking an appearance similar to trichomal elaiophores. The mixed secretions accumulate within subcuticular spaces and may be released either by a natural rupture of the cuticle (B. coccolobifolia and $P$. reticulata) or by a sudden rupture caused by the bee activity ( $B$. variabilis).
\end{abstract}

Handling editor: Louis P. Ronse De Craene.

Silvia R. Machado

smachado@ibb.unesp.br

1 Agricultural Sciences Institute, UFMG - Federal University of Minas Gerais, Montes Claros, Minas Gerais 39404-547, Brazil

2 Department of Botany, Institute of Biosciences of Botucatu, UNESP - Univ Estadual Paulista, Botucatu, São Paulo 18618-970, Brazil
Different bees were observed exploiting the elaiophores, acting as potential pollinators or oil robbers. A greater diversity of oil-collecting bees was registered in $B$. variabilis. The differences identified, mainly in relation to the location of the glands on the sepals, in the fine structure of secretory epithelia and cuticle architecture, and in their secretion release mechanisms, in some way, can affect the behavior of visitors.

Keywords Banisteriopsis $\cdot$ Byrsonima $\cdot$ Electron microscopy $\cdot$ Light microscopy $\cdot$ Oil secretion $\cdot$ Peixotoa

\section{Introduction}

Elaiophores are floral glands that produce nonvolatile oils as reward for the potential pollinators, oil-collecting bees. It is estimated that they occur in 1500-2400 species belonging to at least 11 families and seven orders of monocots and eudicots (see Vogel 1974; Simpson and Neff 1981; Buchmann 1987; Rasmussen and Olesen 2000; Renner and Schaefer 2010; Possobom and Machado 2017). With the exception of the monocots Iridaceae and Orchidaceae that can bear epithelial or trichomal elaiophores, all the other families (Calceolariaceae, Cucurbitaceae, Krameriaceae, Malpighiaceae, Plantaginaceae, Primulaceae, Scrophulariaceae, Solanaceae and Stilbaceae) bear only one of the two gland types (see Possobom and Machado 2017 and references therein).

There are almost 400 species of solitary bees belonging to the Melittidae and Apidae (sensu Michener 2007) which have specialized oil-collecting structures in their abdomen or in their front and/or middle legs (Vogel 1974; Neff and Simpson 1981; Machado 2004; Alves-dos-Santos et al. 2007; Renner and Schaefer 2010). Oil collection is 
normally performed by female bees, which use the oil for larval provisioning (Vogel 1974; Vinson et al. 1997; Reis et al. 2007), for cell lining (Neff and Simpson 1981; Simpson and Neff 1981; Buchmann 1987; Vogel 1990), or as 'glue' for combining soil, sand, wood chips or other materials used in nest construction (Vinson et al. 1996). Some male bees have also been recorded oil collecting, but this behavior was associated with mating and not with parental care or nest construction (see Cappellari et al. 2012).

The Malpighiaceae represents the oldest clade that has acquired oil glands, and it is probably the most important plant family offering oil as floral resource (Vogel 1974; Renner and Schaefer 2010). In this family, elaiophores are considered a synapomorphy (Anderson 1990), occurring in pairs on the abaxial surface of the sepals of most Neotropical species (Vogel 1974, 1990; Anderson 1979, 1990).

Neotropical Malpighiaceae species $(\approx 1150)$ have very uniform flowers mainly due to zygomorphy, the presence of sepal elaiophores and of five free and clawed petals, with the posterior one differentiated from the others (Anderson 1979; Davis and Anderson 2010). Such uniformities are especially related to the attraction, orientation and reward of pollinators (Anderson 1979; Davis and Anderson 2010), which are Neotropical oil-collecting bees belonging mainly to Centridini and Tapinotaspidini tribes (Apidae) (see Vogel 1974; Neff and Simpson 1981; Buchmann 1987; Machado 2004; Alves-dos-Santos et al. 2007; Mello et al. 2013). Paleotropical species $(\approx 150)$, which have lost the oil-pollination syndrome, exhibit diverse floral morphologies generally lacking the characteristic zygomorphy and sepal glands (Davis and Anderson 2010). If the sepal glands are present, however, they are smaller, intersepalics and seem to act as extranuptial nectaries (Vogel 1974, 1990). According to Davis and Anderson (2010) the Paleotropical Malpighiaceae species belong to nine clades that are more closely related to the Neotropical ones than to each other. Based on morphological and biogeographical evidences, some authors (Anderson 1979; Davis and Anderson 2010) have hypothesized that the floral conservatism in Neotropical Malpighiaceae is better explained by extrinsic factors (e.g., stabilizing selection imposed by the specialized bees), which was later supported by the results from Davis et al. (2014).

Despite the importance of elaiophores as mediators of such specialized interactions and consequently in the evolution of the family, few studies have investigated the anatomical (Vogel 1974; Subramanian et al. 1990; Cocucci et al. 1996; Araújo and Meira 2016) and subcellular organization, functioning and life span (Castro et al. 2001; Possobom et al. 2015) of these glands from a comparative perspective. In general, the elaiophores are quite similar among species, being oval, sessile or stalked and they are basically constituted by a secretory palisade-like epithelium with a thick cuticle and a vascularized parenchyma (Vogel 1974; Subramanian et al. 1990; Castro et al. 2001; Possobom et al. 2015; Araújo and Meira 2016). Based on these available data, the epithelial cells arrangement, the cuticle thickness and cuticle breaks to release secretion are the main variable features among Malpighiaceae elaiophores. In this context, we believe that more detailed studies of such secretory structures may reveal peculiarities related to gland structure and functioning, as well as secretion composition. Such features can directly affect how each species interacts with its floral visitors, and they should provide a better understanding of how this family has evolved. Furthermore, in recent phylogenetic studies of the Malpighiaceae (Davis and Anderson 2010; Davis et al. 2014), characters such as calyx gland number, location of glands, attachment and presence of long-stalked glands were considered, thus reinforcing the importance of elaiophore morphology in an evolutionary context.

Therefore, here we conduct a detailed study of the elaiophores of three representative species of the Malpighiaceae and compared the patterns of distribution and dimensions of these glands within their calices, their structural organization, their histochemistry and their life spans. We also report the presence and behavior of elaiophore-visiting insects. The studied species (Byrsonima coccolobifolia Kunth, Banisteriopsis variabilis B. Gates and Peixotoa reticulata Griseb.) represent a particularly good model for a comparative study since they are sympatric and belong to different clades. According to Davis and Anderson (2010), while Byrsonima belongs to a basal clade (byrsonimoids), the other two genera belong to a more derived clade (stigmaphylloids).

\section{Materials and methods}

\section{Study site, plant material and field observations}

This study was conducted from April 2009 to April 2011 among natural and sympatric populations of Byrsonima coccolobifolia, Banisteriopsis variabilis and Peixotoa reticulata growing in cerrado sensu stricto physiognomy. The study site is a fragment of nearly 180 ha, characterized by a continuous herbaceous strata and a sparse woody component (savanna formation) located within Pratânia municipality, São Paulo State, Brazil (between $22^{\circ} 48^{\prime} 48.8^{\prime \prime} \mathrm{S}$ and $48^{\circ} 44^{\prime} 33.7^{\prime \prime} \mathrm{W}$ ), at an altitude of approximately $700 \mathrm{~m}$. Cerrado is characterized by a marked climatic seasonality. The climate is characterized as a Cfa hot climate with rains in the summer and drought in the winter, with average temperature in the hottest month above $22{ }^{\circ} \mathrm{C}$, with small hydric deficiencies in April, July and August (Cunha and Martins 2009). 
For each of the three species, ten plants were marked with a numbered label and were monthly monitored. In general, the individuals of $B$. coccolobifolia were located near the edge of the fragment and they were more spaced apart from each other than the individuals of B. variabilis and $P$. reticulata, which were predominantly located in the interior of the fragment. Focal field observations were made between 06:00 and 18:00 $\mathrm{h}$ during the flowering peak periods to record interactions between elaiophores and visiting bees. Plants of $B$. coccolobifolia flowered from October to January with a peak in the late November, when they were observed for a total of $20 \mathrm{~h}$. Plants of B. variabilis flowered from February to June, with a peak that persisted from April to May, when they were observed for $38 \mathrm{~h}$. Few of the labeled plants of $P$. reticulata flowered from June to September, and the observations were made for $15 \mathrm{~h}$ in August.

Additionally, a set of young buds without visible damage was selected and protected with voile bags to prevent contact between visitors and their elaiophores. Pre-anthesis buds and 1-day flowers (bagged and un-bagged) were collected for structural, histochemical and ultrastructural studies.

Voucher samples of the studied species were deposited at the Irina Delanova Gemtchujnicov Herbarium (BOTU) of the Biosciences Institute, São Paulo State University (UNESP) at Botucatu, São Paulo, Brazil, under the numbers 28442-28448 (B. variabilis), 27630-27632 (B. coccolobifolia), and 28441 (P. reticulata).

\section{Elaiophore distribution and dimensions}

For each species, the diameter of the calyx, the average number of elaiophores per flower ( $n=30$ flowers) and the dimensions (length and width) of all the elaiophores presents in each flower ( $n=3$ flowers) were obtained using a digital pachymeter (Digimess) under a Leica M205C stereomicroscope.

\section{Light microscopy (LM)}

For histological characterization of the elaiophores, samples were fixed in Karnovsky's solution (Karnovsky 1965), dehydrated in an ethanol series and embedded in methacrylate resin (Historesin ${ }^{\circledR}$, Leica, Wetzlar, Germany) in accordance with the manufacturer's recommended procedure. The sections $(4-6 \mu \mathrm{m})$ were obtained using a Leica RM2255 rotary microtome and were stained with $0.05 \%$ toluidine blue, $\mathrm{pH} 4.5$ (O'Brien et al. 1964). The slides were analyzed using a Leica DMR microscope with image capture system (Leica DFC 425). Photomicrographs from sections of five different samples of elaiophores were used to measure cuticle thickness ( $n=5$ measures) and epithelial cell length and width ( $n=15$ measures), using the software Leica Application Suite LAS.

Histochemical tests were carried out to detect the presence of reducing sugars using Fehling's solution (Sass 1951); of phenolic compounds using ferric chloride (10\%) (Johansen 1940); of starch grains using Lugol reagent (Johansen 1940); of proteins using mercuric bromophenol blue (Mazia et al. 1953); of polysaccharides using acid-Schiff's reagent (PAS) (McManus 1948); of pectin/ mucilage using ruthenium red (0.02\%) (Johansen 1940); and of lipids using Sudan IV (Johansen 1940) and Sudan Black B (Pearse 1980).

In addition, elaiophore secretions were also submitted to a glucose reagent strip test $\left(\right.$ Combur test $\left.{ }^{\circledR}\right)$.

\section{Scanning electron microscopy (SEM)}

For scanning electron microscopy (SEM), samples of glands previously isolated from visitors (with voile bags) and non-isolated samples were fixed in glutaraldehyde (2.5\% with $0.1 \mathrm{M}$ phosphate buffer, $\mathrm{pH} 7.3$ ), post-fixed with osmium tetroxide ( $0.5 \%$ in the same buffer) and dehydrated in a graded ethanol series. After dehydration, the samples were critical-point-dried with carbon dioxide as the exchange medium using a Balzers Union CPD 020, gold coated using a Bal-Tec SCD 050 vacuum sputter coater and examined using a FEI QUANTA 200 microscope (FEI, Hillsboro, OR, USA) at $15 \mathrm{kV}$, in accordance with the conventional methods used in the Electron Microscopy Center, IBB, UNESP.

\section{Transmission electron microscopy (TEM)}

For transmission electron microscopy (TEM), samples were fixed in glutaraldehyde $(2.5 \%$ with $0.1 \mathrm{M}$ phosphate buffer, $\mathrm{pH}$ 7.3) and left overnight at $4{ }^{\circ} \mathrm{C}$. They were then post-fixed with osmium tetroxide (1\% in the same buffer) for $2 \mathrm{~h}$ at room temperature. After incubation in uranyl acetate $(0.5 \%)$, the samples were dehydrated in a graded series of acetone solutions and embedded in Araldite resin. Ultrathin sections were stained with uranyl acetate and lead citrate (Reynolds 1963) and observed under a Tecnai Spirit (FEI) microscope, at $80 \mathrm{kV}$.

\section{Results}

\section{Elaiophore distribution and interactions with oil-collecting bees}

The elaiophores occur in pairs on the abaxial surfaces (Fig. 1) of all five sepals, as in B. coccolobifolia $(10 \pm 0$ glands per flower), or of just four sepals, as in P. reticulata 

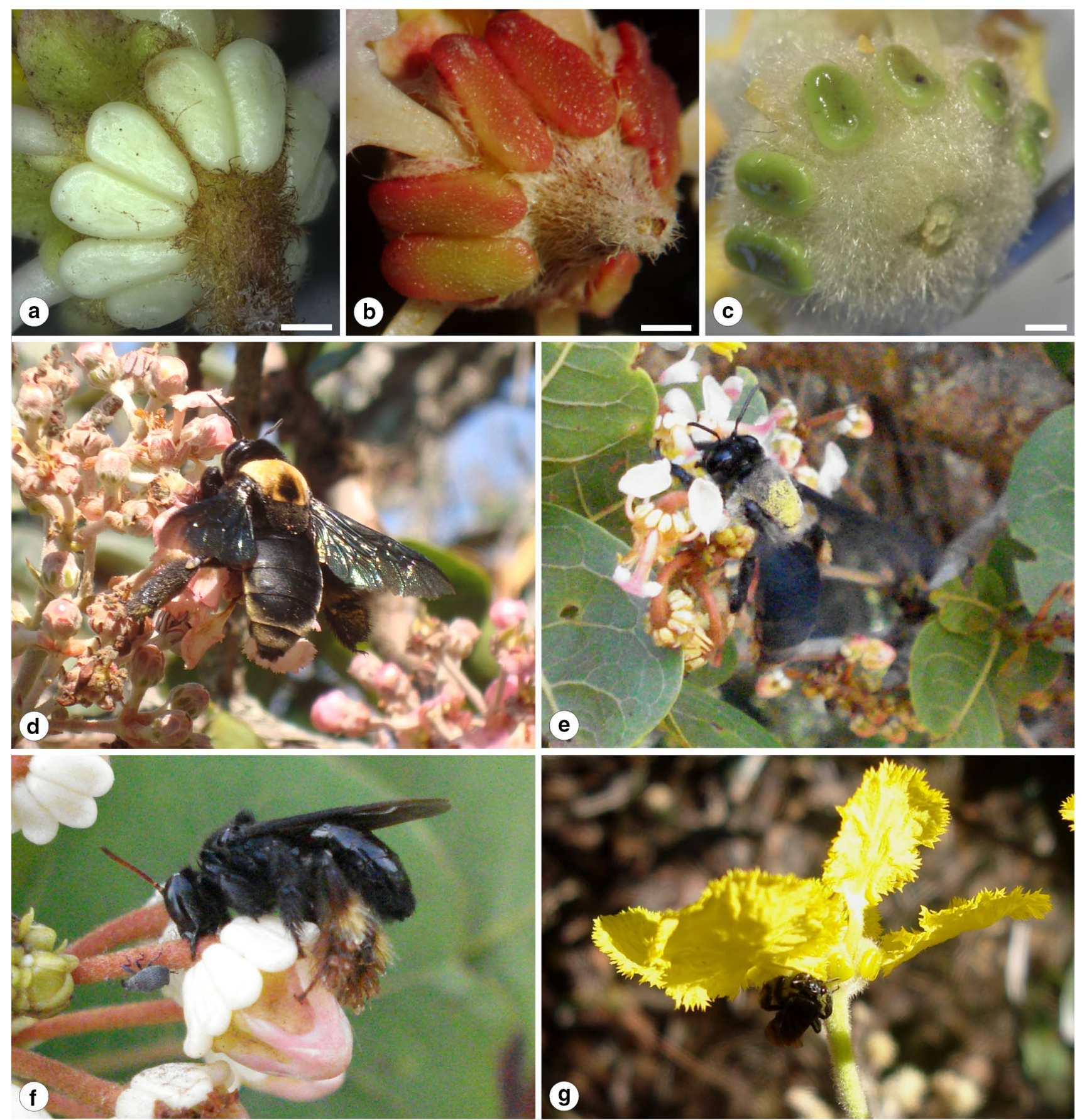

Fig. 1 General morphology of the elaiophores and oil-collecting visitors. a-c Abaxial view from the calyx showing the elaiophores in Byrsonima coccolobifolia (a), Banisteriopsis variabilis (b) and Peixotoa reticulata (c). d-g Oil-collecting visitors of Banisteriopsis

(08 \pm 0 glands per flower) and in most flowers of B. variabilis ( $8.8 \pm 1.6$ glands per flower). In the latter cases, the anterior sepal usually lacks elaiophores.

In B. coccolobifolia, the glands are located at the sepals margins in a way that they are closer to the glands of the neighboring sepals than to each other (Fig. 1a). In contrast, variabilis (d), Byrsonima coccolobifolia (e, f) and Peixotoa reticulata (g). Centris (d) and Epicharis (e) bees contact the flower reproductive parts during oil collection. Tetrapedia $(\mathbf{f}, \mathbf{g})$ bees land directly on the abaxial side of the flowers for oil collection. Scale bars $1 \mathrm{~mm}$

in $B$. variabilis the glands of the same sepal are closer to each other than to those of neighboring sepals (Fig. 1b) and, in $P$. reticulata, they are nearly equidistant (Fig. 1c).

Fourteen species of oil-collecting bees were recorded on the flowers of the three species (Table 1). Ten of them belong to Centridini, Tapinotaspidini and Tetrapediini 
Table 1 Oil-collecting bees (Apidae) of Byrsonima coccolobifolia, Banisteriopsis variabilis and Peixotoa reticulata

\begin{tabular}{|c|c|c|c|c|c|}
\hline Tribe & Visitor & Behavior & $\begin{array}{l}\text { B. coc- } \\
\text { colobifolia }\end{array}$ & B. variabilis & P. reticulata \\
\hline \multirow[t]{7}{*}{ Centridini } & Centris analis & $\mathrm{PP}$ & $\mathrm{X}$ & & \\
\hline & Centris sp. 1 & $\mathrm{PP}$ & & $\mathrm{X}$ & \\
\hline & Centris sp. 2 & PP & & $\mathrm{X}$ & \\
\hline & Epicharis flava & PP & $X$ & & \\
\hline & Epicharis sp. 1 & $\mathrm{PP}$ & & $\mathrm{X}$ & \\
\hline & Morphospecies 01 & PP & & $\mathrm{X}$ & \\
\hline & Morphospecies 02 & $\mathrm{PP}$ & & $\mathrm{X}$ & \\
\hline \multirow[t]{2}{*}{ Tapinotaspidini } & Monoeca sp. 01 & PP & & $\mathrm{X}$ & \\
\hline & Tropidopedia flavolineata & OR & & & $X$ \\
\hline Tetrapediini & Tetrapediasp. 01 & OR & $\mathrm{X}$ & $\mathrm{X}$ & $\mathrm{X}$ \\
\hline \multirow[t]{4}{*}{ Unidentified } & Morphospecies 03 & PP & & $\mathrm{X}$ & \\
\hline & Morphospecies 04 & OR & $\mathrm{X}$ & & \\
\hline & Morphospecies 05 & OR & $X$ & & \\
\hline & Morphospecies 06 & PP & $X$ & & \\
\hline
\end{tabular}

$P P$ potential pollinator, $O R$ oil robber
(Table 1). These bees act as potential pollinators or as oil robbers. In the first case, the ventral part of the abdomen contacts the flower reproductive organs, while the first and second pairs of legs are used to scrape the oil from elaiophores (Fig. 1d, e). The oil robbers land directly on the abaxial side of the flowers for oil collection (Fig. 1f, g). Centris, Epicharis (Centridini) and Monoeca (Tapinotaspidini) bees were considered to be potential pollinators, while Tropidopedia (Tapinotaspidini) and Tetrapedia (Tetrapediini) bees were considered oil robbers (Fig. 1d-g).

Flowers of $B$. variabilis had the greatest diversity of oilcollecting bee visitors ( 8 species), most of these ( 7 species) acting as potential pollinators (Table 1). Flowers of Peixotoa reticulata were visited by two oil-collecting species, acting as oil robber, while $B$. coccolobifolia flowers were visited by six oil-collecting species, three acting as oil robbers and three acting as potential pollinators. Only one oil robber visitor (Tetrapedia sp. 1) was common among all three plant species.

\section{Elaiophore micromorphology}

As viewed under SEM, the elaiophore surfaces are different among the species and they also change during floral development (Fig. 2). The young glands of all species exhibit intact surfaces with cuticles completely adhered to the epithelium.

Young glands of $B$. coccolobifolia exhibit flat and slightly reticulate surfaces with a circular depression of wrinkled appearance near their distal end (Fig. 2a, b). Starting from pre-anthesis, secretions gradually accumulate in a single and wide space, delimited by the cuticle (Fig. 2c, d). In bagged flowers, the elaiophore cuticle ruptures naturally at the distal end (Fig. 2c, detail), that is, at the same place where there was a differentiated, wrinkled area (Fig. 2b). In elaiophores from un-bagged flowers, several transverse disruptions of the cuticle can be seen (Fig. 2d). Presumably, these are results from the mechanical activity of the visitors. The young glands of $B$. variabilis exhibit a flat surface with linear depressions (Fig. 2e). As floral development progresses, the gland surface becomes verrucose due to the formation of several small subcuticular spaces (Fig. 2f-g). The surface exhibits cuticle ruptures only in elaiophores from un-bagged flowers (Fig. 2h). Young glands of $P$. reticulata exhibit flat and slightly roughened surfaces. As in $B$. coccolobifolia, the secretions also accumulate in the subcuticular space (Fig. 2i). From pre-anthesis, the gland cuticle exhibits small pores through which secretion is gradually released (Fig. 2j). As floral development progresses, the number and size of these pores increase. Later, these pores meet each other creating a large rupture that exposes the epithelial cells (Fig. 2k-1). Some un-bagged samples also exhibit transverse breaks in the cuticle that are associated with the activities of visitors (Fig. $2 \mathrm{~m}$ ).

\section{Elaiophore structure and histochemistry}

Under LM, elaiophores exhibit a uniseriate and columnar secretory epithelium with thick cuticle and a parenchyma that is vascularized by xylem and phloem (Fig. 3). Longitudinal sections show that the elaiophores of $B$. coccolobifolia are subsessile, basally inserted in the sepal and have an ellipsoid outline with a slightly convex surface (Fig. 3a). In the other two species they are short-stalked, suprabasally inserted and are cup-shaped with a slightly concave surface (Fig. 3f, 1). 

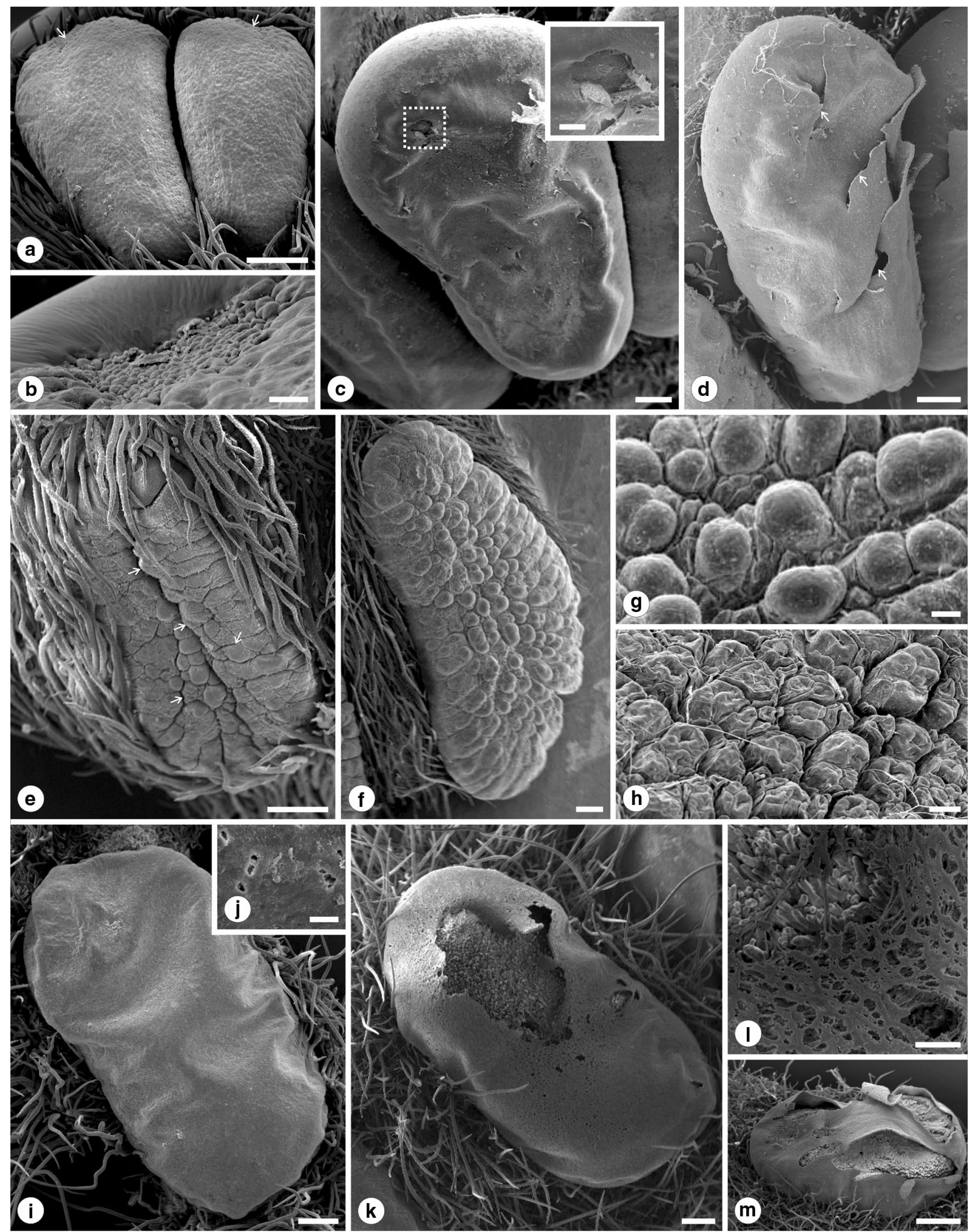
4Fig. 2 Scanning electron micrographs of elaiophores in Byrsonima coccolobifolia (a-d), Banisteriopsis variabilis (e-h) and Peixotoa reticulata $(\mathbf{i}-\mathbf{m})$ : $\mathbf{a}-\mathbf{b}$ young elaiophores with totally adherent cuticle. Note the depression in the distal portion of the gland (arrows) where the cuticle surface is different (b). c Distended cuticle delimiting the subcuticular space where the secretion accumulates. The detail shows the predetermined rupture of the cuticle through which the secretion is naturally released. d Transverse ruptures of the cuticle in a nonisolated sample, in addition to the natural rupture (arrow). e Young elaiophore showing linear depressions (arrows) on the surface and intact cuticle. $\mathbf{f}-\mathbf{g}$ Verrucose surface of isolated elaiophores, showing distended cuticle in some portions, delimiting small subcuticular spaces. h Depleted subcuticular spaces in non-isolated sample. $\mathbf{i}$ Intact and distended cuticle delimiting a wide subcuticular space. $\mathbf{j}$ Detail of the cuticle showing small pores. $\mathbf{k}-\mathbf{l}$ Large natural rupture of the cuticle and exposed epithelial cells. $\mathbf{m}$ Transverse ruptures of the cuticle in an non-isolated sample. Scale bars $200 \mu \mathrm{m}(\mathbf{a}, \mathbf{c}, \mathbf{d}, \mathbf{e}, \mathbf{f}$, $\mathbf{i}, \mathbf{k}), 20 \mu \mathrm{m}(\mathbf{b}, \mathbf{j}), 50 \mu \mathrm{m}(\mathbf{c}$ detail, $\mathbf{g}, \mathbf{h}, \mathbf{l})$ and $500 \mu \mathrm{m}(\mathbf{m})$

Elaiophores of B. coccolobifolia (Fig. 3a-e) and $P$. reticulata (Fig. 31-r) exhibit flat epithelia, while in $B$. variabilis they exhibit a convoluted epithelium (Fig. $3 \mathrm{f}-\mathrm{k}$ ). The epithelial cells are higher in $B$. variabilis and $P$. reticulata (Table 2). In mature elaiophores of B. coccolobifolia, the epithelial cells are juxtaposed throughout its length (Fig. 3b). In B. variabilis and P. reticulata, the mature epithelium is papillose, with juxtaposed cells in the basal and median regions, and free apex (Fig. $3 \mathrm{~g}, \mathrm{~m}$ ). Histochemical tests indicate primarily lipids, carbohydrates, phenolic substances (absent in B. variabilis) and proteins in secretory cells (Table 3). Reducing sugars (e.g., glucose and fructose) were detected in epithelial cells of $B$. coccolobifolia and $B$. variabilis. In $P$. reticulata secretory cells showed a positive reaction to Fehling's solution after acid hydrolysis (i.e., after addition of $\mathrm{HCl}$ ), indicating the presence of non-reducing sugars (possibly sucrose). Also, a positive reaction for glucose (reagent strips) was observed in the elaiophore secretions of B. coccolobifolia and B. variabilis (Table 3).

In all species, the glandular parenchyma encompasses two well-defined regions: One comprises subepithelial cells and the other comprises cells which gradually merge with the sepal parenchyma (Fig. 3a, b, f, g, 1, m). Vascular tissues usually occur in the boundary between these two parenchymal regions. The subepithelial parenchyma in $B$. coccolobifolia is formed by two layers of small, closely packed cells with vacuoles filled with phenolic substances (Fig. 3a, b; Table 3). In B. variabilis there are one or two layers of rectangular or round cells (Fig. $3 \mathrm{f}-\mathrm{g}$ ), while in $P$. reticulata this region comprises approximately five layers of small cells with large intercellular spaces, tending to an aerenchyma (Fig. 31-m). The innermost region of the glands is constituted by larger cells, generally with larger intercellular spaces and variable contents, which may or may not have vacuoles filled with phenolic substances.
Proteins, polysaccharides and reducing sugars were also detected in these cells (Table 3 ).

The elaiophore cuticle is thicker in B. variabilis and $P$. reticulata than in $B$. coccolobifolia (Table 2 ). In the young stages, the cuticle is adherent to the outer periclinal wall of the epithelial cells in all three species (Fig. 3c, $\mathrm{h}, \mathrm{n}$ ). Just prior to anthesis, the cuticle separates from the epithelial cells and delimits the subcuticular space where secretions (stained primarily with Sudan, Table 3) accumulate (Fig. 3a, d-f, i-k, l, p-r). The images suggest the detached, distended cuticle is less thick than the adherent cuticle. In $B$. variabilis, due to the convoluted secretory surface, several subcuticular spaces are formed in the apex region of the epithelium. However, as an artifact of preparation, the entire cuticle becomes detached from the epithelial cells and forms a single, wide subcuticular space (Fig. 3f). Unlike the other two species, the immature elaiophores of $P$. reticulata have microchannels traversing the cuticle (Fig. 3n), while large disruptions occur in the cuticle of elaiophores in more advanced developmental stages (Fig. 3o).

In all species, the whole cuticle reacts to Sudan IV and Sudan Black, indicating the presence of lipophilic substances (Fig. 3d, i, p; Table 3). The innermost layer of the cuticle, which also stains with toluidine blue, reacts positively to ruthenium red (Fig. $3 e, j, q$ ), indicating the presence of acidic polysaccharides, such as pectin. This same region also reacted to PAS (Table 3) in B. coccolobifolia elaiophores. A positive reaction to PAS was also observed in whole cuticles of $B$. variabilis and $P$. reticulata elaiophores (Fig. 3k, r; Table 3).

\section{Elaiophore ultrastructure and secretion mechanism}

We focused our ultrastructural analyses on the epithelial cells because they are directly involved in the synthesis, transport and elimination of the exudates. Furthermore, the ultrastructural features of parenchyma cells are very similar among the species. These parenchyma cells have thin walls, large and central vacuoles with variable content (see Table 2), voluminous nuclei and dense peripheral cytoplasms with abundant mitochondria and prominent plastids. In $B$. coccolobifolia, the parenchyma plastids resemble those of the epithelial cells. In other species, the parenchyma cells have typical chloroplasts.

The TEM observations revealed both similarities and differences between the epithelial cells of the three species (Figs. 4, 5, 6). Overall, these cells have thin anticlinal and inner periclinal walls with numerous plasmodesmata connecting them to each other and also to the underlying parenchymal cells. Each epithelial cell presents an abundant and organelle-rich cytoplasm, a large and central nucleus and a 


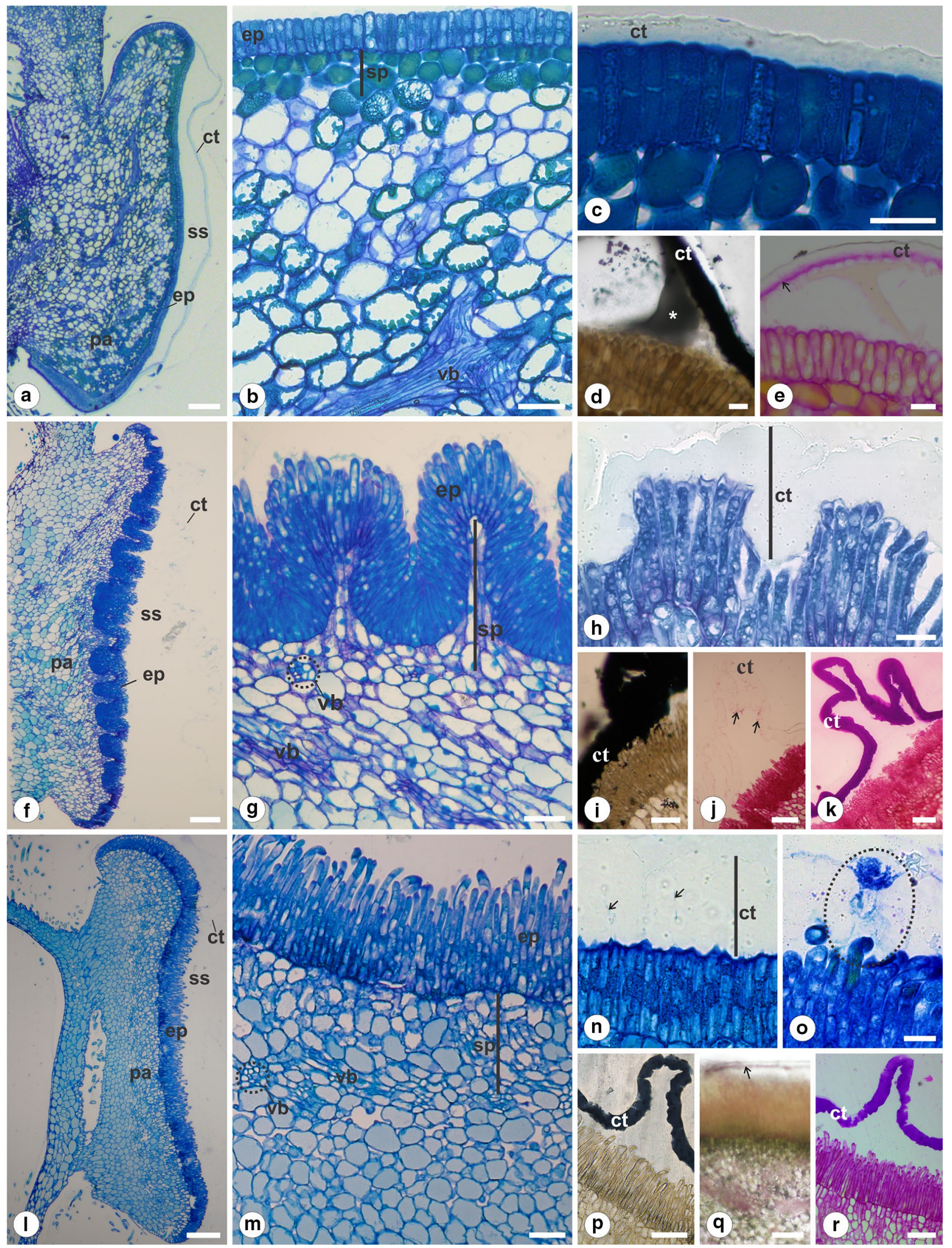


\Fig. 3 Light micrographs of elaiophores in Byrsonima coccolobifolia (a-e), Banisteriopsis variabilis (f-k) and Peixotoa reticulata (1-r): a, $\mathbf{b}, \mathbf{f}, \mathbf{g}, \mathbf{l}, \mathbf{m}$ longitudinal sections of mature glands, showing flat $(\mathbf{a}, \mathbf{b}$, $\mathbf{l}, \mathbf{m})$ or convoluted $(\mathbf{f}, \mathbf{g})$ secretory epithelium $(e p)$, glandular parenchyma $(p a)$ and vascular bundle $(v b)$. The subepithelial parenchyma $(s p)$ is constituted by cells that are different in size, shape, content and arrangement $(\mathbf{b}, \mathbf{g}, \mathbf{m})$. Note the distended cuticle $(c t)$, delimiting the subcuticular space $(s s)$. $\mathbf{c}, \mathbf{h}, \mathbf{n}, \mathbf{o}$ Epithelium of immature elaiophores showing totally adherent cuticle $(c t)$, that is thicker in $\mathbf{h}, \mathbf{n}$ and o. Note microchannels (n-arrows) and pores (o-circle $)$ in the cuticle. d, i, p Sections treated with Sudan Black B. Note strong reaction in the cuticle ( $c t)$ and secretion (*) in the subcuticular space $(s s)$. e, $\mathbf{j}$, q Sections treated with ruthenium red. Note reaction (arrow) in the inner layer of distended cuticle $(c t)$. This layer is relatively thicker in e. $\mathbf{k}, \mathbf{r}$ Sections treated with PAS. Note the positive reaction the in whole cuticle. Scale bars $200 \mu \mathrm{m}(\mathbf{a}, \mathbf{f}, \mathbf{l}), 50 \mu \mathrm{m}(\mathbf{b}, \mathbf{i}, \mathbf{m}), 100 \mu \mathrm{m}(\mathbf{g}$, $\mathbf{j}, \mathbf{k}, \mathbf{p}, \mathbf{q}, \mathbf{r})$ and $20 \mu \mathrm{m}(\mathbf{c}, \mathbf{d}, \mathbf{e}, \mathbf{h}, \mathbf{n}, \mathbf{o})$

well-developed vacuome with variable content. These cells are described in detail below.

Immature elaiophores exhibit juxtaposed epithelial cells due to adhesion between anticlinal walls (Figs. 4a, 5a, 6a). The thick sensu lato cuticle is continuous with the outer periclinal wall (Figs. 4b, 5b, 6b). Between these layers, there is a heterogeneous and more electron-dense stratum (previously identified as a pectic layer) that is connected to the middle lamella of the anticlinal walls. In B. coccolobifolia, the cuticle consists of two distinct layers: an external and more homogeneous one, the cuticle proper (sensu stricto), and an internal and heterogeneous one, the cuticular layer (Fig. 4b). In B. variabilis and P. reticulata the cuticle proper is thin, and the thick cuticular layer presents a lamellar appearance with alternating electron-opaque and electron-dense materials (Figs. 5b-d, 6b-d). In these two species, it is common to find regions of the cuticular layer with a loose appearance (Figs. 5b-c; 6c-d), invaginations (Fig. 5c) and/or transverse fibrous ramifications (Fig. 6b).

As the elaiophores develop, the pectic layer and the outer most layers of the outer periclinal wall dissolve and the cuticle becomes dissociated from the epithelium, creating subcuticular spaces (Figs. 4c, 5c-d, 6c-d). At the same time, there is a loosening or total dissolution of the middle lamella between the anticlinal walls, forming channels where secretions accumulate (Figs. 4d, 5e, 6e-g). The epithelial cells of $B$. coccolobifolia become more distant from one another, but remain adherent due to the material present between their anticlinal walls (Fig. 4d). The total dissolution of the middle lamella occurs in B. variabilis and $P$. reticulata, so the cells become papillose, free from one another-at least at their apices (Figs. 5e, 6g).

The plasma membrane often pulls away from the cell wall, creating periplasmic spaces where multivesicular bodies or electron-dense materials are observed (Figs. $4 \mathrm{f}-\mathrm{h}$; $5 f-h, 6 e-f, h-i)$. Vesicles near to, or fused with the plasma membrane are also common and indicate frequent releases of material into the periplasmic space.
The dense cytoplasm of the secretory cells is rich in free ribosomes, polyribosomes, mitochondria, plastids, endoplasmic reticulum and dispersed oil droplets (Figs. $4 \mathrm{f}-\mathrm{h}$, $5 \mathrm{e}-\mathrm{i}, 6 \mathrm{e}-\mathrm{i})$. Dictyosomes are scarce, but are generally well developed and active in vesicle production (Figs. 4f, h, $5 \mathrm{~g}, 6 \mathrm{f}, \mathrm{i})$. Elongated or globular mitochondria with welldeveloped cristae and scattered ribosomes on the matrix are numerous and generally occur near the plastids (Figs. $4 \mathrm{f}-\mathrm{h}$, $5 \mathrm{f}-\mathrm{i}, 6 \mathrm{e}, \mathrm{h}-\mathrm{i})$. The numerous and voluminous plastids are polymorphic and have dense stroma, few inner membranes, tubular structures, as well as small and large electron-dense and electron-opaque circular inclusions (Figs. $4 \mathrm{f}-\mathrm{h}, 5 \mathrm{f}-\mathrm{i}$, $6 \mathrm{~h}-\mathrm{i}$ ). The endoplasmic reticulum is extensive (Figs. 4e, $\mathrm{h}, 5 \mathrm{f}, \mathrm{i}, 6 \mathrm{e}-\mathrm{f}, \mathrm{h}-\mathrm{i}$ ) and is associated with ribosomes (rough endoplasmic reticulum) in some parts, especially in the immature stages of elaiophore development. The smooth endoplasmic reticulum is predominant in all developmental stages and increases in abundance as development proceeds. In all species, electron-opaque droplets (probably oil) are frequently observed in the cytoplasm of epithelial cells, mainly near the plastids (Figs. 4h, 5g-h, 6h-i). These droplets are larger and more numerous in $B$. variabilis and $P$. reticulata and also increase in number and in size as development proceeds. Vacuoles are usually at the poles of the cells and are filled with granular material (Fig. 4d, $\mathrm{g}-\mathrm{h}$ ), electron-dense material (Figs. 4d, g, 6a, h) or with membranous material (Figs. 4a, 5a, c-e, 6d, g).

\section{Discussion}

Although the three species share similarities regarding the general morphology of elaiophores, and in the nature of their exudates, our detailed studies allowed to identify differences concerning the location of the glands on the sepals, their fine structure (mainly in relation to their secretory epithelia) and their secretion release mechanisms.

As it is common in most Neotropical Malpighiaceae, the three species have appressed and paired elaiophores on the abaxial surfaces of the sepals and these glands are largely similar mainly in their size and shape in frontal view. The similarity in gland size is interesting, given that the calyx diameter and, consequently, flower size vary among these species. Thus, the uniformity of their external morphology can be considered part of the floral conservatism of the Neotropical Malpighiaceae, which is related to maintaining interaction with oil-collecting bees (see Anderson 1979; Davis et al. 2014).

The number of glands per flower varies among the studied species. In the case of B. variabilis, it also varies among flowers within plants. This variation is very common among other Neotropical Malpighiaceae species, regardless of their phylogenetic position. Most 


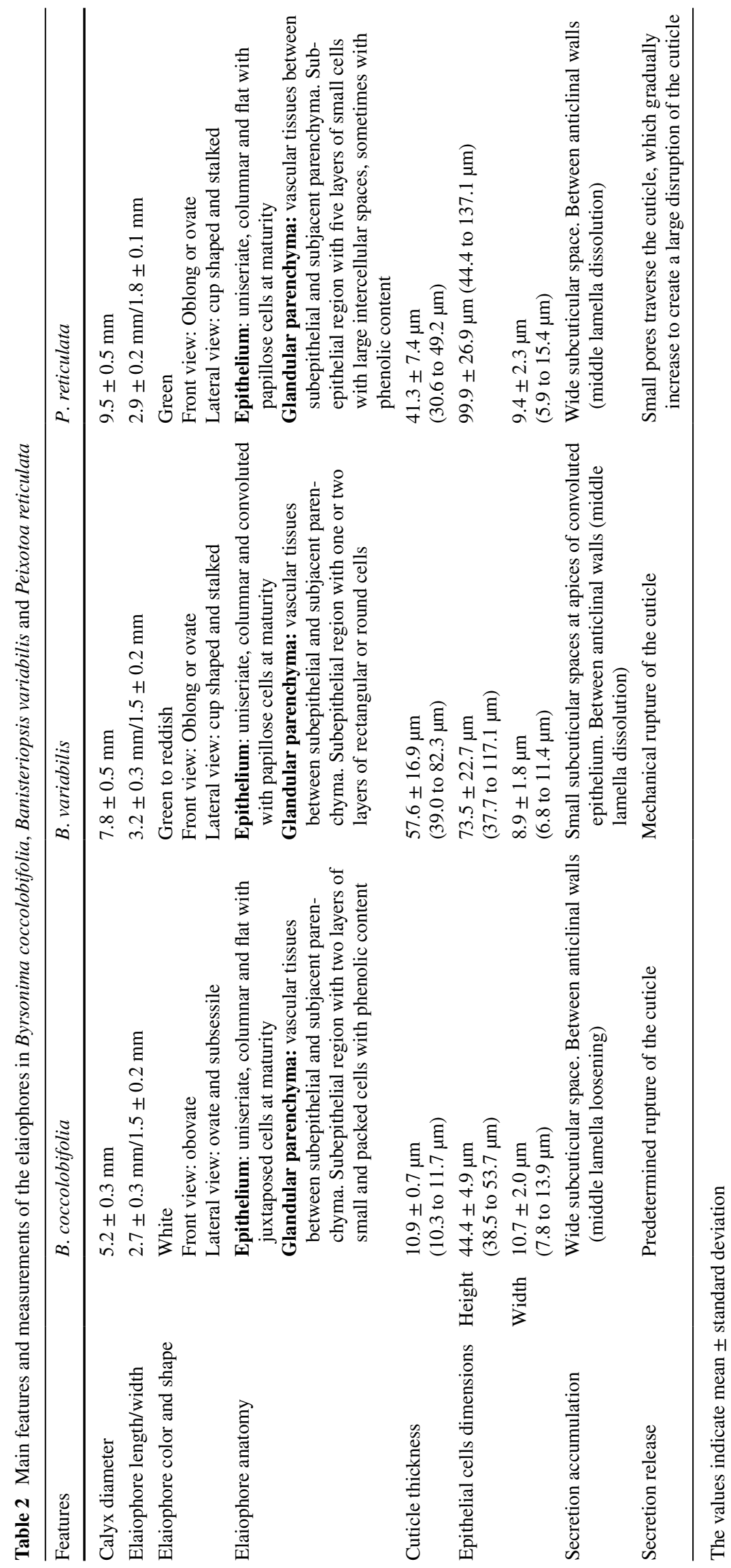


Table 3 Histochemistry and glucose detection in secretion of elaiophores in Byrsonima coccolobifolia, Banisteriopsis variabilis and Peixotoa reticulata

\begin{tabular}{|c|c|c|c|c|}
\hline \multirow[t]{2}{*}{ Staining procedure } & \multirow[t]{2}{*}{ Target compounds } & \multicolumn{3}{|l|}{ Positive reaction site } \\
\hline & & B. coccolobifolia & B. variabilis & $P$. reticulata \\
\hline Mercuric bromophenol blue & Proteins & $\begin{array}{l}\text { Subcuticular space, cyto- } \\
\text { plasm and nucleus (EC, } \\
\text { PC) }\end{array}$ & $\begin{array}{l}\text { Cytoplasm and nucleus (EC, } \\
\text { PC) }\end{array}$ & $\begin{array}{l}\text { Cytoplasm and nucleus (EC, } \\
\text { PC) }\end{array}$ \\
\hline Ferric chloride & Phenolic compounds & Vacuole (EC, PC) & - & Vacuole (EC, PC) \\
\hline Fehling's solution & Reducing sugars & $\begin{array}{l}\text { Subcuticular space, cyto- } \\
\text { plasm (EC, PC) }\end{array}$ & Cytoplasm (EC) & Cytoplasm* (EC, PC) \\
\hline Lugol & Starch & - & - & - \\
\hline Schiff (PAS) & Polysaccharides & $\begin{array}{l}\text { Inner cuticle layer, subcu- } \\
\text { ticular space, cell walls and } \\
\text { cytoplasm (EC, PC) }\end{array}$ & $\begin{array}{l}\text { Cuticle, subcuticular space, } \\
\text { cell walls and cytoplasm } \\
\text { (EC, PC) }\end{array}$ & $\begin{array}{l}\text { Cuticle, subcuticular space, } \\
\text { cell walls and cytoplasm } \\
\text { (EC, PC) }\end{array}$ \\
\hline Sudan Black B & Lipids & $\begin{array}{l}\text { Cuticle, subcuticular space, } \\
\text { cytoplasm and vacuole } \\
\text { (EC) }\end{array}$ & $\begin{array}{l}\text { Cuticle, subcuticular space, } \\
\text { cytoplasm and vacuole } \\
\text { (EC) }\end{array}$ & $\begin{array}{l}\text { Cuticle, subcuticular space, } \\
\text { cytoplasm and vacuole } \\
\text { (EC) }\end{array}$ \\
\hline Sudan IV & Lipids & $\begin{array}{l}\text { Cuticle, subcuticular space, } \\
\text { cytoplasm and vacuole } \\
\text { (EC) }\end{array}$ & $\begin{array}{l}\text { Cuticle, subcuticular space, } \\
\text { cytoplasm and vacuole } \\
\text { (EC) }\end{array}$ & $\begin{array}{l}\text { Cuticle, subcuticular space, } \\
\text { cytoplasm and vacuole } \\
\text { (EC) }\end{array}$ \\
\hline Ruthenium red & $\begin{array}{l}\text { Acids polysac- } \\
\text { charides (pectin/ } \\
\text { mucilage) }\end{array}$ & $\begin{array}{l}\text { Inner cuticle layer, subcu- } \\
\text { ticular space, cell walls and } \\
\text { cytoplasm (EC, PC) }\end{array}$ & $\begin{array}{l}\text { Inner cuticle layer, cell walls } \\
\text { and cytoplasm (EC, PC) }\end{array}$ & $\begin{array}{l}\text { Inner cuticle layer, cell walls } \\
\text { and cytoplasm (EC, PC) }\end{array}$ \\
\hline Combur test $^{\circledR}$ & Glucose & Secretion & Secretion & - \\
\hline
\end{tabular}

$E C$ epithelial cell, $P C$ parenchyma cell

* Positive reaction after $\mathrm{HCl}$ addition

Byrsonima species, for example, have two glands in each sepal, but some species have no glands (Anderson 1981, 2001) or present individuals with glandular flowers and other individuals with eglandular flowers, as in Byrsonima sericea (Teixeira and Machado 2000). In Peixotoa species (Anderson 1982), the anterior sepals frequently lack glands. In Banisteriopsis species, the glands can be totally absent in all or in some flowers (Gates 1982; Buchmann 1987; Sazima and Sazima 1989), or most commonly, they can be absent only in the anterior sepals (Gates 1982). There are also many examples in which the number of glands varies among flowers, such as in Galphimia brasiliensis (Castro et al. 2001), Heteropterys alternifolia (Costa et al. 2006), Pterandra pyroidea (Cappellari et al. 2011), Stigmaphyllon paralias (Carvalho et al. 2005; Costa et al. 2006) and Diplopterys pubipetala (Possobom et al. 2015). According to Vogel (1990), flowers that tend to actinomorphy usually have calyx glands in pairs in all five sepals, as with most Byrsonima species. In more derived flowers, e.g., those that are markedly zygomorphic as $B$. variabilis and $P$. reticulata, the differential guidance of the posterior petal can affect visitor behavior so the secretion produced by elaiophores on the anterior sepals becomes inaccessible (Vogel 1990). Thus, the absence of or reduction in the number of the calyx glands can be considered a derived feature (Anderson 1979, 1990) and may represent a form of energy saving (Vogel 1990) or a more efficient usage of energy resources, as demonstrated by Carvalho et al. (2005) in Stigmaphyllon paralias. However, there are cases in which the absence of or reduction in the elaiophores indicates a transition to a pollination system where pollen is the main reward, instead of oil, as in Pterandra pyroidea (Cappellari et al. 2011).

The elaiophores of the byrsonimoid (sensu Davis and Anderson 2010) representative (B. coccolobifolia) differ from the elaiophores of the stigmaphylloid (sensu Davis and Anderson 2010) representatives (B. variabilis and P. reticulata) in relation to the attachment to the sepal and surface shape. In the first case they exhibit convex surfaces and they are subsessile, marginally and basally inserted on the sepals. In the other two species, they exhibit cup-shaped, concave surfaces and they are short-stalked, more centrally and suprabasally inserted on the sepals. The presence of a stalk, even of a short one, may represent a more efficient usage of energy resources, since the secretory cells are restricted to the upper, exposed, surfaces of the glands, as in B. variabilis and $P$. reticulata. In sessile or subsessile elaiophores, as in $B$. coccolobifolia, almost all the epithelium is constituted by secretory cells. Sessile or subsessile glands also occur in Malpighia glabra (Vogel 1974), Hiptage sericea (Subramanian et al. 1990) and Diplopterys pubipetala (Possobom 


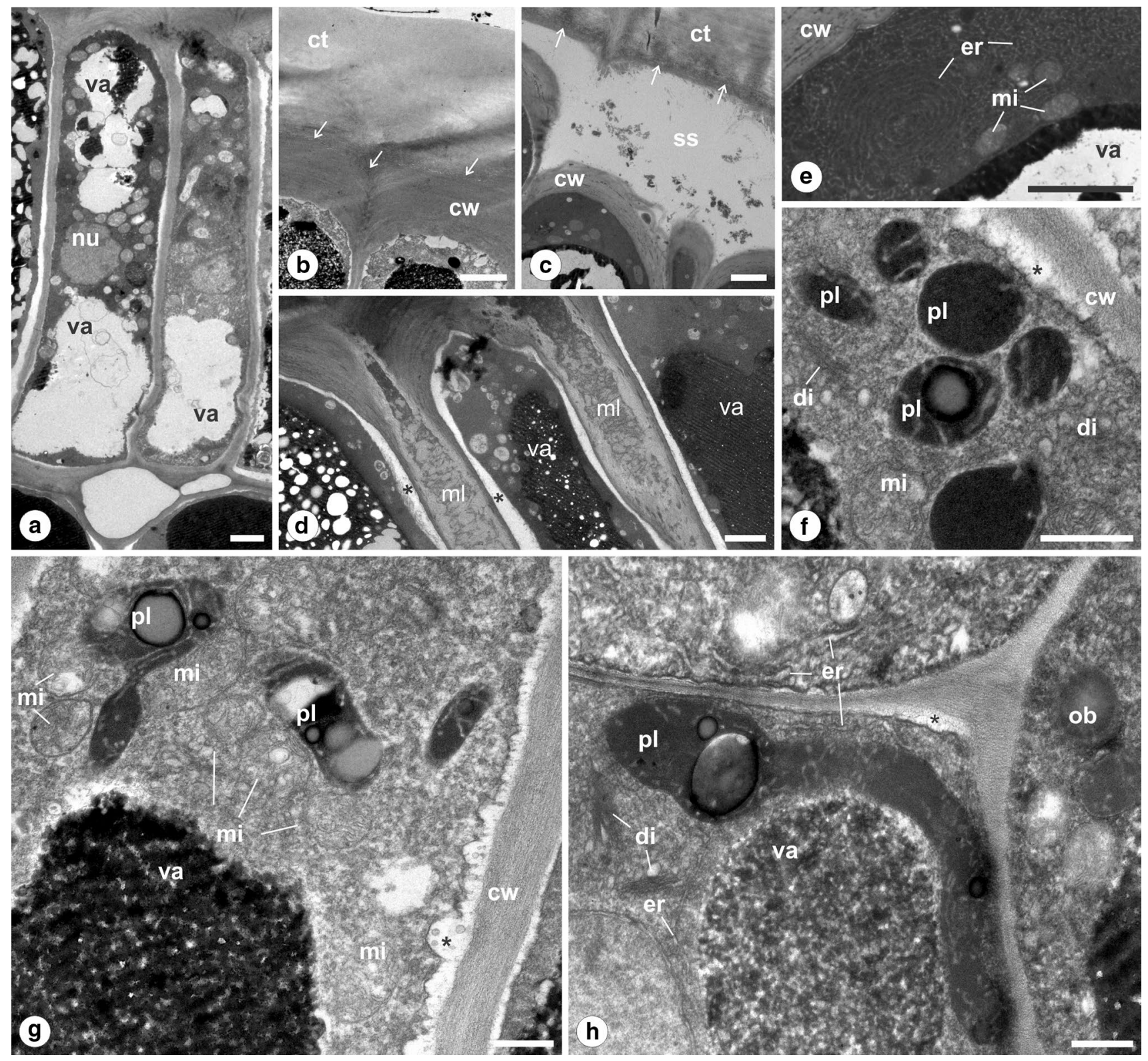

Fig. 4 Transmission electron micrographs of elaiophore secretory epithelium in Byrsonima coccolobifolia: a juxtaposed cells with thin anticlinal and inner periclinal walls, conspicuous nucleus (nu), dense and abundant cytoplasm and peripheral vacuoles $(v a)$ with variable contents. b Detail of the outer periclinal cell wall $(\mathrm{cw})$ continuous to the sensu lato cuticle $(c t)$. Note an external and more homogeneous stratum (sensu stricto cuticle) and an inner and more heterogeneous one (cuticular layer). The arrows indicate the pectic layer. c Subcuticular space ( $s s)$ delimited by the cuticle $(c t)$ and outer periclinal cell

et al. 2015). The glands of the Banisteriopsis species studied by Araújo and Meira (2016) were described as subsessile, but the image presented seems to show a short-stalked gland. According to Simpson (1989), in the Malpighiaceae, only species belonging to Dinemandra, Dinemagonum, Heladena and Henleophytum present long-stalked elaiophores. wall $(c w)$. Note the more electron-dense material (pectin) in the inner stratum of the cuticle (arrows). d Loosening of the middle lamella $(\mathrm{ml})$. Note the accumulation of electron-dense material between anticlinal walls of adjacent cells and the wide periplasmic space (*). e-h Details of the dense and abundant cytoplasm with plastids $(p l)$, mitochondria ( $m i)$, endoplasmic reticulum (er), dictyosome $(\mathrm{di})$ and oil bodies $(o b)$. Note outer periclinal wall with electron-dense material (in $e$ ) and periplasmic spaces with vesicles (*). Scale bars $2 \mu \mathrm{m}(\mathbf{a}, \mathbf{b}$, c, d, e) and $500 \mathrm{~nm}(\mathbf{f}, \mathbf{g}, \mathbf{h})$

Coincidently, these genera belong to closely related clades, the ptilochaetoids (Dinemandra and Dinemagonum) and tristellateioids (Heladena and Henleophytum) according to Davis and Anderson (2010). The presence and size of the stalk in these glands seems to be a variable feature in Malpighiaceae, and so it could be helpful to taxonomic studies. 

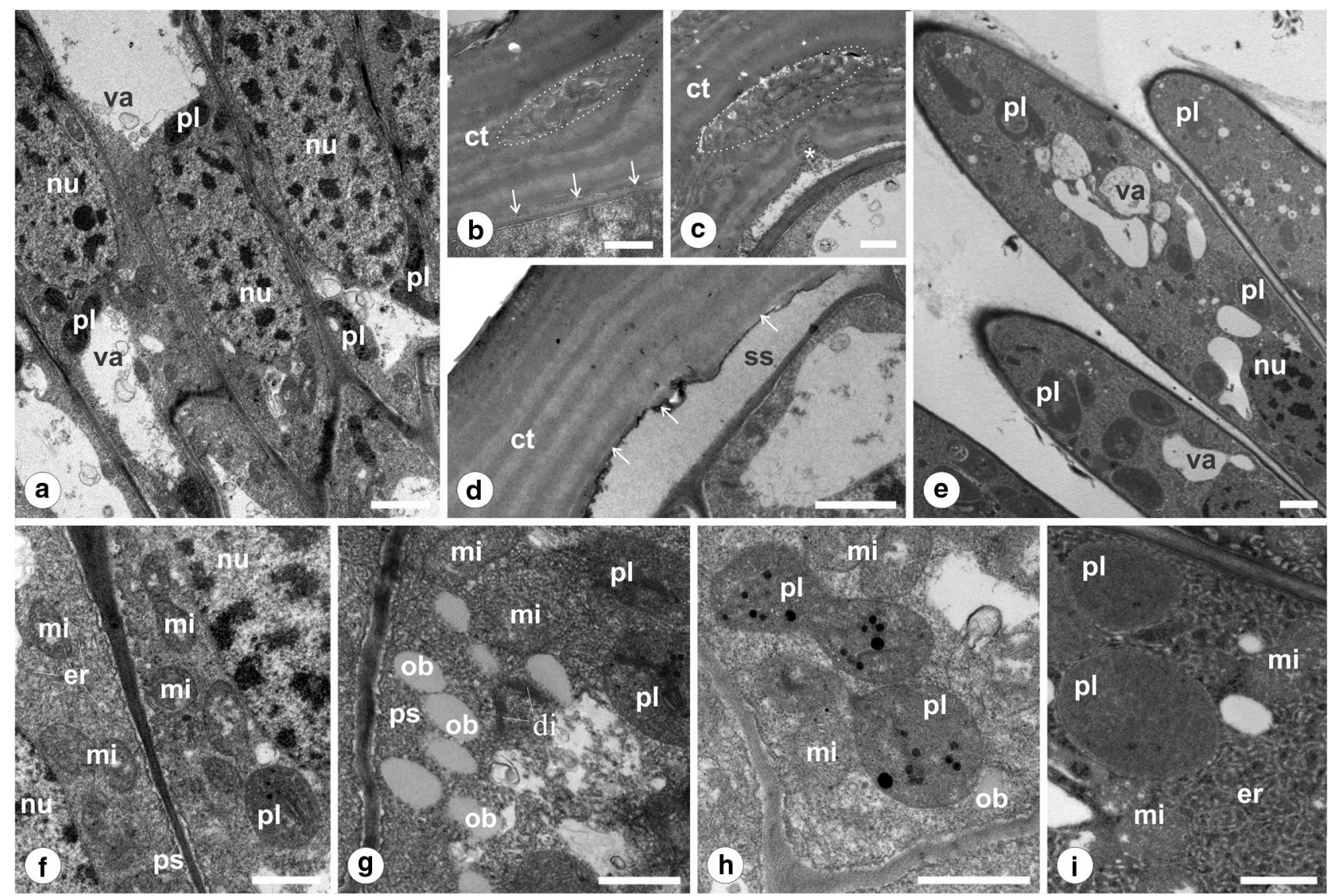

Fig. 5 Transmission electron micrographs of elaiophores in Banisteriopsis variabilis: a juxtaposed cells with thin anticlinal and inner periclinal walls, conspicuous nucleus $(n u)$, dense and abundant cytoplasm with conspicuous plastids $(p l)$ and peripheral vacuoles $(v a)$. b, c Detail of the outer periclinal cell wall and sensu lato lamellated cuticle $(c t)$. Note the dissolution of the pectic layer (arrows), areas with loose appearance (dotted ellipse) and invaginations (*) in the inner stratum. d Subcuticular space (ss) delimited by the cuti-

However, there is little information on this and no described pattern to allow an accurate classification. In addition, this feature can also play a role in the interaction with oil-collecting bees as hypothesized by Simpson (1989). According to this author, the presence of a stalk increases the distance between the ventral side of the flower and the secretory surface of the glands on the dorsal side, thus allowing oil gathering by the larger Centris bees in small flowers as occurs in the Dinemandra and Dinemagonum species.

Epithelial elaiophores exhibiting a similar anatomical pattern to the ones described here have been reported in all species of Malpighiaceae studied, both Neotropical and Paleotropical (Vogel 1974; Lorenzo 1981; Subramanian et al. 1990; Mamede 1993; Cocucci et al. 1996; Laskowski and Bautista 1999; Castro et al. 2001; Possobom et al. 2015; Araújo and Meira 2016), as well as in some species of Krameriaceae (Vogel 1974; Simpson 1982) and cle $(c t)$ and thin outer periclinal cell wall. Note the very thin layer of electron-dense material (pectin) in the inner stratum of the cuticle (arrows). e Papillose cells without middle lamella between the anticlinal walls of the adjacent cells. $\mathbf{f}-\mathbf{i}$ Details of the dense and abundant cytoplasm with plastids $(\mathrm{pl})$, mitochondria $(\mathrm{mi})$, endoplasmic reticulum (er), dictyosome ( $d i)$ and oil bodies $(o b)$. Note the periplasmic spaces (ps). Scale bars $2 \mu \mathrm{m}(\mathbf{a}, \mathbf{d})$ and $1 \mu \mathrm{m}(\mathbf{b}, \mathbf{c}, \mathbf{f}, \mathbf{g}, \mathbf{h}, \mathbf{i})$

Orchidaceae (Stpiczyńska et al. 2007; Stpiczyńska and Davies 2008; Davies and Stpiczyńska 2009). However, our data pointed out several interesting structural peculiarities of the elaiophores of the analyzed species.

The epithelia of $B$. coccolobifolia and $P$. reticulata are flat, as is common in other Neotropical species of Malpighiaceae, such as Heteropterys chrysophylla, Malpighia glabra (Vogel 1974), Janusia guaranitica (Lorenzo 1981), Camarea affinis (Mamede 1993), Dinemandra ericoides (Cocucci et al. 1996), Malpighia emarginata (Laskowski and Bautista 1999), Galphimia brasiliensis (Castro et al. 2001) and Diplopterys pubipetala (Possobom et al. 2015). Meanwhile, $B$. variabilis has convoluted epithelium, which has also been described in other Banisteriopsis species (Araújo and Meira 2016), in Stigmaphyllon littorale (Vogel 1974) and in a Paleotropical species, Hiptage sericea (Subramanian et al. 1990), all include in the stigmaphylloid clade (Davis 

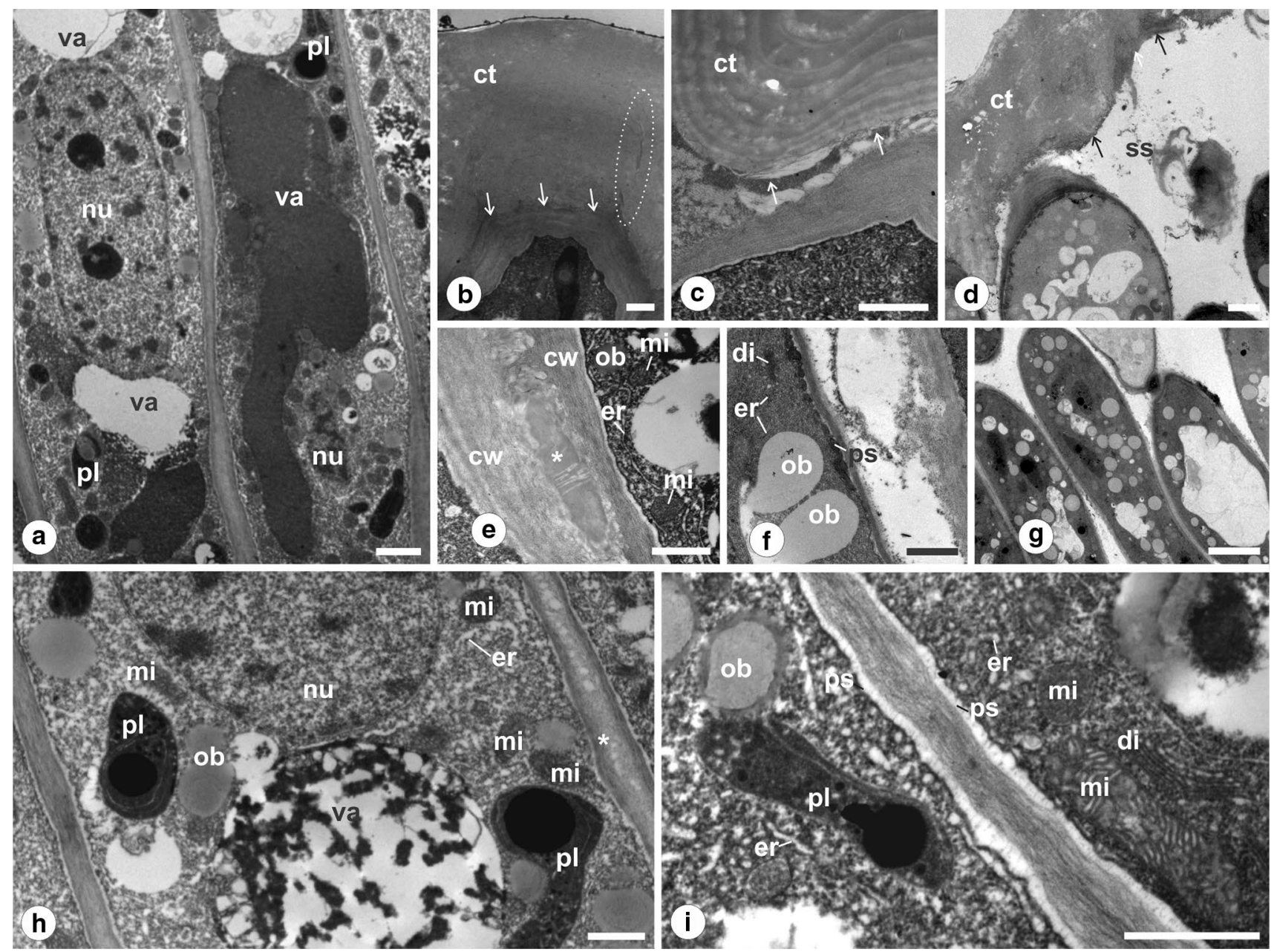

Fig. 6 Transmission electron micrographs of elaiophores in Peixotoa reticulata: a juxtaposed cells with thin anticlinal walls, conspicuous nucleus $(n u)$, dense and abundant cytoplasm with conspicuous plastids $(p l)$ and vacuoles $(v a)$. b, $\mathbf{c}$ Detail of the outer periclinal cell wall and sensu lato lamellated cuticle $(c t)$. Note dissolution of the pectic layer (arrows), areas with loose appearance and fibrous ramification (dotted ellipse). d Subcuticular space ( $s s)$ delimited by the cuticle $(c t)$ and outer periclinal cell wall. Note the very thin layer of electrondense material (pectin) in the inner stratum of the cuticle (arrows). e, f Loosening and dissolution of middle lamella. Note secretion accu-

and Anderson 2010). According to Vogel (1974), the convolution of the epithelium potentially increases the secretory surface and thus the amount of secretion produced. Moreover, elongated and narrow epithelial cells which become papillose, as observed in $B$. variabilis and $P$. reticulata, may also contribute to an increase in secretory surface. These free epithelial cells (papillose) in the stigmaphylloid representatives indicate similarity to trichomal elaiophores, in contrast to the epithelial cells of the B. coccolobifolia, which are less elongated and remain juxtaposed at maturity.

The exudate of the elaiophores in the three species is predominantly lipophilic; however, the presence of other compounds, such as carbohydrates, indicates these mulation (*) between anticlinal cell walls $(c w)$, periplasmic space ( $p s)$ filled with electron-dense substance and dense cytoplasm with mitochondria ( $m i)$, endoplasmic reticulum $(e r)$, dictyosome $(\mathrm{di})$ and oil bodies $(o b)$. g Papillose cells without middle lamella between anticlinal walls. h, i Details of the dense and abundant cytoplasm with plastids $(p l)$, mitochondria $(m i)$, endoplasmic reticulum (er), dictyosome $(d i)$ and oil bodies $(o b)$. Note conspicuous nucleus $(n u)$, vacuole (va) with granular substance and periplasmic space ( $p s)$. Scale bars $2 \mu \mathrm{m}(\mathbf{a}, \mathbf{d}), 1 \mu \mathrm{m}(\mathbf{b}, \mathbf{c}, \mathbf{e}, \mathbf{f}, \mathbf{h}, \mathbf{i})$ and $5 \mu \mathrm{m}(\mathbf{g})$

glands produce mixed secretions. The presence of carbohydrates in elaiophore secretion has also been reported in other Neotropical Malpighiaceae species (Lobreau-Callen 1989; Vinson et al. 1997; Castro et al. 2001). According to Vogel $(1974,1990)$, this points to some kind of homology between the elaiophores of Neotropical species and the extranuptial nectaries of Paleotropical species. In this aspect, Anderson (1990) discusses the possibility of transformation between them, based on their morphological similarity and the existence of diverse functions (nectaries and elaiophores) for the same structures (calyx glands), but does not indicate with certainty the path of this transformation. However, the absence of detailed studies on these 
structures and their secretions, that compare large numbers of Paleotropical and Neotropical species, as well as information on the behavior of the floral visitors in Paleotropical species, hinders any conclusion in this respect.

As it is typical in the elaiophores of many species and families (Castro et al. 2001; Stpiczyńska et al. 2007; Stpiczyńska and Davies 2008; Aliscioni et al. 2009; Davies and Stpiczyńska 2009; Pacek et al. 2012; Davis et al. 2014; Possobom et al. 2015), the secretory cells here, in addition to abundant oil droplets throughout the cytoplasm, have extensive, smooth endoplasmic reticula (SER), numerous modified plastids and well-developed mitochondria. Modified plastids are frequently cited as the main site of fatty acid synthesis (Fahn 1979; Douce and Joyard 1990; Kunst and Samuels 2003), and fatty acids are generally the main component of elaiophores secretions (see Vogel 1974; Seigler et al. 1978; Buchmann 1987; Simpson 1989; Subramanian et al. 1990; Reis et al. 2007). The presence of numerous mitochondria, often in contact with the plastids, also suggests the large energy demand of these organelles (Stern et al. 1987), which is in line with the intense secretory activity of the epithelial cells. In addition, these organelles, jointly with the plastids and endoplasmic reticulum, are also associated with lipid metabolism (Schmid and Ohlrogge 2002).

The abundance of SER, dictyosomes active in production of vesicles located close to or being incorporated into the plasma membrane, and membranous structures within the vacuole and/or in the periplasmic space, all indicate that the secretions reach the periplasmic space by exocytosis (granulocrine secretion). This is similar to that occurring with the components of wax, which are also produced by plastids and transported directly from the endoplasmic reticulum to the plasma membrane or involve the participation of vesicles produced by dictyosomes (Kunst and Samuels 2003). In addition, the presence of oil droplets dispersed throughout the cytoplasm also suggests they reach the periplasmic space without the participation of membranes (eccrine secretion), as commonly described for other lipophilic glands (Paiva and Machado 2006; Paiva et al. 2008, Paiva 2016; Sadala-Castilho et al. 2016). Both pathways seem to occur in the secretory cells of the elaiophores studied here. It is possible that these two pathways account for the different components of the exudate.

From the periplasmic space, the secretion traverses the outer periclinal cell wall to reach the subcuticular space. Alternatively, it can be released between the anticlinal cell walls where the middle lamella is loosening (B. coccolobifolia) or totally dissolved (only in $B$. variabilis and $P$. reticulata), and from there, the secretion moves to the subcuticular space. In all species, the origins of the subcuticular space seem to be related to the dissolution of the pectic layer between the outer periclinal cell wall and the sensu lato cuticle. It is possible that the outer layers of the outer periclinal cell wall are also dissolved in this process.

Detailed analysis of the cuticle enables us to understand the release mechanisms of exudate onto the elaiophore surface. In B. coccolobifolia, there is a clear separation of the sensu lato cuticle into two layers of similar dimensions. First, there is the cuticle sensu stricto (or cuticle proper) where lipid substances were histochemically detected, and second, there is the cuticular layer where lipid and polysaccharide substances were detected. This model resembles the type 2 and type 3 situations described by Holloway (1982). Both P. reticulata and B. variabilis exhibit a lamellated cuticle (in LM and in TEM preparations), which excludes the possibility of artifact. This model of a lamellated cuticle resembles the type 5 described by Holloway (1982 and references therein). However, we did not detect the presence of wax layers interspersed with layers of cutin. Our histochemical analyses show a tenuous layer of sensu stricto cuticle and a thicker lamellated layer (cuticular layer) consisting of alternating layers of lipids and polysaccharides. These cuticle features appear to be phylogenetically related, indicating that the cuticle may also represent a character with potential taxonomic value. In addition, we suppose that these characteristics may be related to higher or lower degrees of cuticle resistance and elasticity, influencing how the secretion is released (see discussion below). It is likely that the cuticle structure of $B$. coccolobifolia is related to a higher resistance, while that in the other species is related to a higher elasticity. The images suggest the elaiophore cuticles of $B$. variabilis and $P$. reticulata have greater distension with large increases in length, compared to those in B. coccolobifolia.

The accumulation of secretions in a subcuticular space before release is a common feature, also reported for epithelial and trichomal elaiophores in a range of species (Vogel 1974; Simpson 1982; Subramanian et al. 1990; Cocucci 1991; Cocucci and Vogel 2001; Cocucci et al. 1996; Castro et al. 2001; Steiner and Whitehead 2002; Pacek and Stpiczyńska 2007, Stpiczyńska et al. 2007, Pacek et al. 2012; Possobom et al. 2015). Here, the accumulation starts in the elaiophores of young buds, with gradual increases in the amount of secretion toward anthesis. In B. coccolobifolia and $P$. reticulata, a single and wide subcuticular space is formed, while in $B$. variabilis, due to the convoluted epithelium, several small subcuticular spaces are formed at the apex of each undulation. Regardless of the type of elaiophore (trichomal or epithelial), the secretion can either permeate the intact cuticle (Cocucci and Vogel 2001; Stpiczyńska et al. 2007; Stpiczyńska and Davies 2008; Aliscioni et al. 2009; Pansarin et al. 2009) or it can be released by cuticle disruption (Vogel 1974; Simpson 1982; Cocucci 1991; Cocucci and Vogel 2001; Steiner and Whitehead 2002; Stpiczyńska et al. 2007; Stpiczyńska 
and Davies 2008). In B. coccolobifolia, the secretion is released naturally by a predetermined rupture of the cuticle. In this case, the scraping of the glands by visitor activity can enhance or facilitate secretion release, as also suggested by Pacek and Stpiczyńska (2007) for two Orchidaceae species. This type of secretion release occurs in other Malpighiaceae species such as Malpighia glabra, Stigmaphyllon littorale and Heteropterys chrysophylla (Vogel 1974). In $P$. reticulata, the secretion is also released naturally, but initially secretion occurs through many small pores on the cuticle which progressively combine creating a broad disruption of the cuticle, so the entire surface of the papillose epithelial cell layer is exposed. The secretion remains exposed on the gland surface, filling the spaces between the epithelial cells from before anthesis. In this case, a visitor can gather a large amount of secretion in a single visit. In B. variabilis, the secretion is released only upon rupture of the cuticle caused by the mechanical action of the visitor. This is the most common mechanism in Malpighiaceae elaiophores (Subramanian et al. 1990; Cocucci et al. 1996; Castro et al. 2001; Possobom et al. 2015). In this species, the undulating shape of the epithelium prevents a sudden widespread discharge, since cuticle rupture occurs separately in each small subcuticular space. This may represent a way of conserving energy resources and/or an adaptation that increases visits, since the resource would take longer to run out.

Centris, Epicharis and Monoeca bees were the main visitors of B. variabilis and B. coccolobifolia, displaying similar collecting behavior and acting as potential pollinators. In general, most of these bees have similar oil-collecting apparatuses which are combs of rigid setae located in the inner margins of the basitarsi on the front and middle legs (see Neff and Simpson 1981). This "four-leg" pattern probably represents an adaptation to explore the epithelial elaiophores like the ones found in the Malpighiaceae species (see Vogel 1974; Neff and Simpson 1981). Tetrapedia and Tropidopedia bees, in turn, have the oil-collecting apparatuses restricted to the outer margin of the basitarsi on the front legs (see Neff and Simpson 1981; Michener 2007). For this reason these bees collect the oil from elaiophores landing directly on the abaxial side of the flowers, thus acting as oil robbers.

We recorded more legitimate oil-collecting visitors to $B$. variabilis than to the other plant species. This fact could be associated with the structural and functional features of elaiophores discussed here and with other floral features such as more pronounced zygomorphy in relation to the B. coccolobifolia and the presence and functioning of other floral glands that may increase the attractiveness of this species (C.C.F. Possobom, unpublished data). An interesting fact is that $P$. reticulata did not receive any legitimate visits of oil-collecting bees, although all the floral features indicate great attractiveness. According to Anderson (1982), almost all the known populations of $P$. reticulata are apomictic and have indehiscent anthers with low pollen viability. This is probably the case of the study population, in which few individuals flower each year, the anthers are indehiscent, few visits are recorded, but fruit production is intense (C.C.F. Possobom, unpublished data). One explanation would be the occurrence of a genetically controlled reduction in the investments on floral attractives, e.g., changes in the quantity or composition of the elaiophore secretions. Similar hypothesis was proposed by Cappellari et al. (2011) to explain the total absence of oil-collecting visitors to the eglandular and also to the glandular flowers of Pterandra pyroidea.

In conclusion, our study allows us to identify peculiarities with respect to elaiophore functioning with clear implications for the secretion release mechanism and, therefore, for how each plant species interacts with its floral visitors. Therefore, we presume that in addition to the macroscopic characters (which are already used in phylogenetic studies of Malpighiaceae, see Davis and Anderson 2010; Davis et al. 2014) the anatomical and ultrastructural characters of elaiophores will contribute to a better understanding of the forces driving evolution in Malpighiaceae.

Acknowledgements This manuscript is a part of the thesis of the first author (Programa de Pós-Graduação em Ciências Biológicas - Botânica, IBB/UNESP) and was supported by the Coordenação de Aperfeiçoamento de Pessoal de Nível Superior (CAPES) and Fundação de Amparo à Pesquisa do Estado de São Paulo (FAPESP BIOTA-08/55434-7 and DR-08/57650-9). The authors would like to thank the technicians of the Electron Microscopy Center (CME), IBB/ UNESP, for laboratory assistance, Dr. M.C.H. Mamede for plant identification and Dr. A. Aguiar for bee identification.

\section{References}

Aliscioni SS, Torretta JP, Bello ME, Galati BG (2009) Elaiophores in Gomesa bifolia (Sims) M.W. Chase \& N.H. Williams (Oncidiinae: cymbidieae: Orchidaceae): structure and oil secretion. Ann Bot (Oxford) 104:1141-1149. doi:10.1093/aob/mcp199

Alves-dos-Santos I, Machado IC, Gaglianone MC (2007) História natural das abelhas coletoras de óleo. Oecol Brasil 11:544-557

Anderson WR (1979) Floral conservatism in Neotropical Malpighiaceae. Biotropica 11:219-223

Anderson WR (1981) Malpighiaceae. Mem New York Bot Gard 32:21-305

Anderson C (1982) A monograph of the genus Peixotoa (Malpighiaceae). Contr Univ Michigan Herb 15:1-92

Anderson WR (1990) The origin of the Malpighiaceae - The evidence from morphology. Mem New York Bot Gard 64:210-224

Anderson WR (2001) Malpighiaceae. In: Berry PE, Yatskievych K, Holst BK (eds) Flora of the Venezuelan Guayana, vol. 6. Missouri Botanical Garden Press, St. Louis, pp 82-185

Araújo JS, Meira RMSA (2016) Comparative anatomy of calyx and foliar glands of Banisteriopsis C. B. Rob. (Malpighiaceae). Acta Bot Brasil 30:112-123. doi:10.1590/0102-33062015abb0248 
Buchmann SL (1987) The ecology of oil flowers and their bees. Annual Rev Ecol Syst 18:343-369. doi:10.1146/annurev. es.18.110187.002015

Cappellari SC, Haleem MA, Marsaioli AJ, Tidon R, Simpson BB (2011) Pterandra pyroidea: a case of pollination shift within Neotropical Malpighiaceae. Ann Bot (Oxford) 107:1323-1334. doi:10.1093/aob/mcr084

Cappellari SC, Melo GAR, Aguiar AJC, Neff JL (2012) Floral oil collection by male Tetrapedia bees (Hymenoptera: Apidae: Tetrapediini). Apidologie 43:39-50. doi:10.1007/ s13592-011-0072-2

Carvalho PD, Borba EL, Lucchese AM (2005) Variação no número de glândulas e produção de óleo em flores de Stigmaphyllon paralias A. Juss. (Malpighiaceae). Acta Bot Brasil 19:209214. doi:10.1590/S0102-33062005000200002

Castro MA, Vega AS, Múlgura ME (2001) Structure and ultrastructure of leaf and calyx glands in Galphimia brasiliensis (Malpighiaceae). Amer J Bot 88:1935-1944. doi:10.2307/3558420

Cocucci AA (1991) Pollination biology of Nierembergia (Solanaceae). Pl Syst Evol 174:17-35. doi:10.1007/BF00937691

Cocucci AA, Vogel S (2001) Oil producing flowers of Sisyrinchium species (Iridaceae) and their pollinators in southern South America. Flora 196:26-46. doi:10.1016/ S0367-2530(17)30010-5

Cocucci AA, Holgado AM, Anton AM (1996) Estudio morfológico y anatómico de los eleóforos pedicelados de Dinemandra ericoides, Malpighiácea endémica del desierto de Atacama, Chile. Darwiniana 34:183-192. doi:10.14522/ darwiniana.2014.341-4.404

Costa CBN, Costa JAS, Ramalho M (2006) Biologia reprodutiva de espécies simpátricas de Malpighiaceae em dunas costeiras da Bahia, Brasil. Revista Brasil Bot 29:103-114. doi:10.1590/ S0100-84042006000100010

Cunha AR, Martins D (2009) Classificação climática para os municípios de Botucatu e São Manuel-SP. Irriga 14:1-11

Davies KL, Stpiczyńska M (2009) Comparative histology of floral elaiophores in the orchids Rudolfiella picta (Schltr.) Hoehne (Maxillariinae sensu lato) and Oncidium ornithorhynchum H.B.K. (Oncidiinae sensu lato). Ann Bot (Oxford) 104:221-234. doi:10.1093/aob/mcp119

Davis CC, Anderson WR (2010) A complete generic phylogeny of Malpighiaceae inferred from nucleotide sequence data and morphology. Amer J Bot 97:2031-2048. doi:10.3732/ajb.1000146

Davis CC, Schaefer H, Xi Z, Baum DA, Donoghue MJ, Harmone LJ (2014) Long-term morphological stasis maintained by a plantpollinator mutualism. Proc Natl Acad Sci USA 111:5914-5919. doi:10.1073/pnas.1403157111

Douce R, Joyard J (1990) Biochemistry and function of the plastid envelope. Annual Rev Cell Biol 6:173-216. doi:10.1146/ annurev.cb.06.110190.001133

Fahn A (1979) Secretory Tissues in Plants. Academic Press, New York

Gates B (1982) Banisteriopsis and Diplopterys (Malpighiaceae). Fl Neotrop Monogr 30:1-237

Holloway PJ (1982) Structure and histochemistry of plant cuticular membranes: an overview. In: Cutler DF, Alvin KL, Price CE (eds) The plant cuticle. Academic Press, London, pp 45-85

Johansen DA (1940) Plant michrotechnique. McGraw-Hill, New York

Karnovsky MJ (1965) A formaldehyde-glutaraldehyde fixative of high osmolarity for use in electron microscopy. J Cell Biol 27:137-138

Kunst L, Samuels AL (2003) Biosynthesis and secretion of plant cuticular wax. Progr Lipid Res 42:51-80. doi:10.1016/ S0163-7827(02)00045-0

Laskowski LE, Bautista D (1999) Caracteristicas anatomicas de la flor del semeruco (Malpighia emarginata DC.). Ernstia 9:19-36
Lobreau-Callen D (1989) Les Malpighiaceae et leurs pollinisateurs. Coadaptation ou coévolution. Bull Mus Natl Hist Nat B Adansonia 11:79-94

Lorenzo E (1981) Sobre la inflorescencia, morfologia floral y embriologia de Janusia guaranitica (Malpighiaceae). Kurtziana 14:101-124

Machado IC (2004) Oil-Collecting bees and related plants: a review of the studies in the last twenty years and case histories of plants occurring in NE Brazil. In: Freitas BM, Pereira JOP (eds) Solitary bees: conservation, rearing and management for pollination. Imprensa Universitária, Fortaleza, pp 255-280

Mamede MCH (1993) Estudo comparativo de flores casmógamas, cleistógamas e de frutos de Camarea affins St. Hil. (Malpighiaceae). Acta Bot Brasil 7:21-31. doi:10.1590/ S0102-33061993000100002

Mazia D, Brewer PA, Alfert M (1953) The cytochemical staining and measurement of protein with mercuric bromophenol blue. Biol Bull Mar Biol Lab Woods Hole 104:57-67

McManus JFA (1948) Histological and histochemical uses of periodic acid. Stain Technol 26:99-108

Mello MAR, Bezerra ELS, Machado IC (2013) Functional roles of Centridini oil bees and Malpighiaceae oil flowers in biome-wide pollination networks. Biotropica 45:45-53. doi:10.1111/j.1744-7429.2012.00899.x

Michener CD (2007) The bees of the world, 2nd edn. John Hopkins University Press, Baltimore

Neff JL, Simpson BB (1981) Oil-collecting structures in the Anthoporidae (Hymenoptera): morphology, function and use in systematics. J Kansas Entomol Soc 54:95-123

O'Brien TP, Feder N, McCully ME (1964) Polychromatic staining of plant cell walls by toluidine blue O. Protoplasma 59:368-373

Pacek A, Stpiczyńska M (2007) The structure of elaiophores in Oncidium cheirophorum Rchb.F. and Ornithocephalus kruegeri Rchb.F. (Orchidaceae). Acta Agrobot 60:9-14. doi:10.5586/ aa.2007.024

Pacek A, Stpiczyńska M, Davies KL, Szymezak G (2012) Floral elaiophore structure in four representatives of the Ornithocephalus clade (Orchidaceae: Oncidiinae). Ann Bot (Oxford) 110:809820. doi:10.1093/aob/mcs158

Paiva EAS (2016) How do secretory products cross the plant cell wall to be released? A new hypothesis involving cyclic mechanical actions of the protoplast. Ann Bot (Oxford). doi:10.1093/aob/ mcw012

Paiva EAS, Machado SR (2006) Ontogênese, anatomia e ultraestrutura dos nectários extraflorais de Hymenaea stigonocarpa Mart. ex Hayne (Fabaceae - Caesalpinioideae). Acta Bot Brasil 20:471-482. doi:10.1590/S0102-33062006000200022

Paiva EAS, Oliveira DMT, Machado SR (2008) Anatomy and ontogeny of the pericarp of Pterodon emarginatus Vogel (Fabaceae, Faboideae), with emphasis on secretory ducts. Anais Acad Brasil Ci 80:455-465. doi:10.1590/S0001-37652008000300007

Pansarin LM, Castro MM, Sazima M (2009) Osmophore and elaiophores of Grobya amherstiae (Catasetinae, Orchidaceae) and their relation to pollination. Bot J Linn Soc 159:408-415. doi:10.1111/j.1095-8339.2009.00953.x

Pearse AGE (1980) Histochemistry theoretical and applied, vol. 2, 4th edn. Longman Press, London

Possobom CCF, Machado SR (2017) Elaiophores: their taxonomic distribution, morphology and functions. Acta Bot Brasil. doi:10.1590/0102-33062017abb0088

Possobom CCF, Guimarães E, Machado SR (2015) Structure and secretion mechanisms of floral glands in Diplopterys pubipetala (Malpighiaceae), a neotropical species. Flora 211:26-39. doi:10.1016/j.flora.2015.01.002

Rasmussen C, Olesen JM (2000) Oil flowers and oil-collecting bees. Skr Norske Vidensk-Akad Oslo Mat-Naturvidensk Kl 39:23-31 
Reis MG, Faria AD, Alves-dos-Santos I, Amaral MCE, Marsaioli AJ (2007) Byrsonic acid - the clue to floral mimicry involving oil-producing flowers and oil-collecting bees. J Chem Ecol 33:1421-1429. doi:10.1007/s10886-007-9309-y

Renner SS, Schaefer H (2010) The evolution and loss of oil-offering flowers: new insights from dated phylogenies for plants and bees. Philos Trans Roy Soc London 365:423-435. doi:10.1098/ rstb.2009.0229

Reynolds ES (1963) The use of lead citrate at high $\mathrm{pH}$ as an electronopaque stain in electron microscopy. J Cell Biol 17:208

Sadala-Castilho R, Machado SR, Sá-Haiad B, Lima HA (2016) Oil-resin glands in Velloziaceae flowers: structure, ontogenesis and secretion. Pl Syst Evol 302:585-599. doi:10.1007/ s00606-016-1287-5

Sass JE (1951) Botanical microtechnique. Iowa Press Building, Iowa

Sazima M, Sazima I (1989) Oil-gathering bees visit flowers and glandular morphs of the oil-producing Malpighiaceae. Bot Acta 102:106-111. doi:10.1111/j.1438-8677.1989.tb00073.x

Schmid KM, Ohlrogge JB (2002) Lipid metabolism in plants. In: Vance DE, Vance JE (eds) Biochemistry of lipids, lipoproteins and membranes. Elsevier, Amsterdam

Seigler D, Simpson BB, Martins C, Neff JL (1978) Free 3-acetoxyfatty acids in floral glands of Krameria species. Phytochemistry 17:995-996

Simpson BB (1982) Krameria (Krameriaceae) flowers: orientation and elaiophore morphology. Taxon 31:517-528

Simpson BB (1989) Pollination biology and taxonomy of Dinemandra and Dinemagonum (Malpighiaceae). Syst Bot 14:408-426

Simpson BB, Neff JL (1981) Floral rewards: alternatives to pollen and nectar. Ann Missouri Bot Gard 68:301-322
Steiner KE, Whitehead VB (2002) Oil secretion and the pollination of Colpias mollis (Scrophulariaceae). Pl Syst Evol 235:53-66. doi:10.1007/s00606-002-0216-y

Stern WS, Curry KJ, Pridgeon AM (1987) Osmophores of Stanhopea (Orchidaceae). Amer J Bot 74:1323-1331

Stpiczyńska M, Davies KL (2008) Elaiophore structure and oil secretion in flowers of Oncidium. Ann Bot (Oxford) 101:375-384. doi:10.1093/aob/mcm297

Stpiczyńska M, Davies KL, Gregg A (2007) Elaiophore diversity in three contrasting members of the Oncidiinae Benth. (Orchidaceae). Bot J Linn Soc 155:135-148. doi:10.1111/j.1095-8339.2007.00681.x

Subramanian RB, Arumugasamy K, Inamdar JS (1990) Studies in secretory glands of Hiptage sericea (Malpighiaceae). Nordic $\mathbf{J}$ Bot 10:57-62. doi:10.1111/j.1756-1051.1990.tb01753.x

Teixeira LAG, Machado IC (2000) Sistema de polinização e reprodução de Byrsonima sericea DC (Malpighiaceae). Acta Bot Brasil 14:347-357. doi:10.1590/S0102-33062000000300011

Vinson SB, Frankie GW, Williams HJ (1996) Chemical ecology of bees of the genus Centris (Hymenoptera: Apidae). Fla Entomol 79:109-129. doi:10.2307/3495809

Vinson SB, Williams HJ, Frankie GW, Shrum G (1997) Floral lipid chemistry of Byrsonima crassifolia (Malpighiaceae) and a use of floral lipid by Centris bees (Hymenoptera: Apidae). Biotropica 29:76-83. doi:10.1111/j.1744-7429.1997.tb00008.x

Vogel S (1974) Ölblumen und ölsammelnde Bienen. Trop Subtrop Pflanzenwelt 7:283-547

Vogel S (1990) History of Malpighiaceae in the light of pollination ecology. Mem New York Bot Gard 55:130-142 